УДК: 336.1: 339.7

\title{
КОНКУРЕНТНІ ПОЗИЦІЇ УКРАЇНИ НА СВІТОВОМУ РИНКУ ФІНАНСОВИХ ПОСЛУГ
}

\author{
ЛИТВИН Олена Євгенівна \\ к.е.н., дочент кафедри цүифрової \\ та міжнародної економіки \\ Навчально-наукового інституту економічних та сочіальних відносин \\ Університету банківської справи \\ ORCSD ID: http://orcid.org/0000-0003-3437-2067 \\ e-mail: kafedra_mm@ukr.net

\section{ХМЕЛЕВСЬКА Вікторія Владиславівна} \\ бакалаврант Навчально-наукового інституту економічних та сочіальних \\ відносин Університету банківської справи \\ e-mail:wersaweya@gmail.com
}

Анотація. Світовий ринок фінансових послуг займає одне з провідних місиь в структурі світової економіки. Разом з изим відбувається постійний рух і перерозподіл ресурсів між учасниками міжнародних економічних відносин. Саме тому визначення рівня конкурентоспроможності України та посилення ї̈ конкурентних переваг на світовому ринку фінансових послуг $\epsilon$ пріоритетним завданням формування економічної стратегії держави.

Ключові слова: конкурентоспособность, мировой рынок, финансовые услуги.

Постановка проблеми. Суспільний розвиток країн сьогодні формується під впливом глобалізаційних зрушень та процесів економічної інтеграції. Посилення фінансової складової глобалізації є однією з найважливіших іiі властивостей сучасного етапу. В результаті глобального кругообігу капіталів і пов'язаних 3 ними послуг продовжує формуватися новий рівень вза-
Аннотация. Мировой рынок финансовых услуг занимает одно из ведущих мест в структуре мировой экономики. Вместе $c$ этим происходит постоянное движение и перераспределение ресурсов между участниками международных экономических отношений. Именно поэтому определение уровня конкурентоспособности Украинь и усиления ее конкурентных преимуществ на мировом рынке финансовых услуг является приоритетной задачей формирования экономической стратегии государства.

Ключевые слова: конкурентоспособность, мировой рынок, финансовые услуги.

ємозалежності економік різних країн світу. Зростаючі масштаби фінансових ресурсів обертаються в різноманітних сферах економічної активності і справляють дедалі більший вплив на розвиток світового господарства. Разом 3 цим відбувається постійний рух і перерозподіл ресурсів між учасниками міжнародних економічних відносин. Саме тому визначення рівня конку- 
рентоспроможності України та посилення ii конкурентних переваг на світовому ринку фінансових послуг $\epsilon$ пріоритетним завданням формування економічної стратегії держави.

Аналіз останніх досліджень і публікацій. Питанням оцінювання загальної конкурентоспроможності України на світовому ринку фінансових послуг присвячено наукові публікації низки вітчизняних вченихекономістів, зокрема Т.М. Боровик, Є.І. Войнової, О.А. Деревко, А.І. Дернової, Л.В. Кравченко, О.І. Лютого, В.В. Прядка та ін. Їх напрацювання становлять вагомий внесок у формування теоретико-методологічних та концептуальних засад розвитку світового ринку фінансових послуг в умовах глобалізації. Проте розгляд шляхів нарощення конкурентних позицій України на світовому ринку фінансових послуг досі не набув достатнього втілення у вітчизняній науковій літературі. Це визначає необхідність подальших досліджень у даній сфері.

Метою статті $\epsilon$ оцінка конкурентних позицій України на світовому ринку фінансових послуг, виокремлення проблем та розроблення рекомендацій щодо їх нарощення.

Виклад основного матеріалу. Як інфраструктурний елемент світовий ринок фінансових послуг займає одне 3 провідних місць в структурі світової економіки. Рівень розвиненості ринку фінансових послуг в країні корелює 3 іiї економічним розвитком і відображає потенціал майбутнього економічного зростання. Саме тому визначення рівня конкурентоспроможності України та посилення іiі конкурентних переваг на світовому ринку фінансових послуг $\epsilon$ пріоритетним завданням формування економічної стратегії держави.
Найвідомішим рейтингом міжнародної конкурентоспроможності країн, зокрема на світовому ринку фінансових послуг, $є$ «індекс глобальної конкурентоспроможності» (Global Competitiveness Index), який, розраховується за методикою Всесвітнього економічного форуму (World Economic Forum) з $1996 \mathrm{p}$.

Оцінювання здійснюється за 12 основними компонентами, що формують конкурентоспроможність країни, які визначаються на підставі 114 економічних індикаторів. У 2019 p. Україна посіла 85-е місце в рейтингу серед 141 країни світу, що погіршило позицію країни в рейтингу на дві позиції за рахунок макроекономічної стабільності $(-2,0)$, якості інститутів ($1,6)$ та динамічності бізнесу $(-1,9)$, опустившись до показника трирічної давнини. За всі роки Україна, беручи участь у рейтингу, не піднімалася вище 68-го місця зі 125 країн у 2005 р. Згідно 3 оціночними судженнями експертів стосовно базових показників (1-7), прослідкуємо, як змінювалися позиції України в даному рейтингу (табл. 1) [1].

Загалом, огляд показників ефективності в динаміці свідчить про економічну стабільність країни, незважаючи на поодинокі випадки зниження показників.

Проте, слід зазначити, що індикатор фінансової системи має негативну тенденцію (-6,4 бали та 136-е місце у 2019 р.) за рахунок погіршення показників кредитування приватного сектору (-47,5 бали та 76-е місце у 2019 р.).

Низькими $\epsilon$ також і інші результати за складовими групи «Розвиненість фінансового ринку» (табл. 2): міцність банків (135 місце), простота доступу до кредитів (103), регулювання фон- 
дових бірж (134), фінансування через тощо [2].

місцевий ринок капіталів (114), доступність до фінансових послуг (120)

Таблиця 1

Місце й оцінка (1-7) України в Індексі глобальної конкурентоспроможності за 2010-2018 pp.

\begin{tabular}{|c|c|c|c|c|c|c|c|c|}
\hline $\begin{array}{c}\text { Індекс глобальної конкурентос-- } \\
\text { проможності }\end{array}$ & $\begin{array}{l}2010- \\
2011\end{array}$ & $\begin{array}{l}2011- \\
2012\end{array}$ & $\begin{array}{l}2012- \\
2013\end{array}$ & $\begin{array}{l}2013- \\
2014\end{array}$ & $\begin{array}{l}2014- \\
2015\end{array}$ & $\begin{array}{l}2015- \\
2016\end{array}$ & $\begin{array}{l}2016- \\
2017\end{array}$ & $\begin{array}{l}2017- \\
2018\end{array}$ \\
\hline Місце України в рейтингу & $89 / 139$ & $82 / 142$ & $73 / 144$ & $84 / 148$ & $76 / 144$ & $79 / 140$ & $85 / 138$ & $81 / 137$ \\
\hline Оцінка (1-7) & 3,90 & 4,00 & 4,14 & 4,05 & 4,14 & 4,0 & 4,00 & 4,11 \\
\hline Основні вимоги & 3,9 & 4,2 & 4,4 & 4,3 & 4,4 & 4,1 & 4,0 & 4,2 \\
\hline Інститути & 3,0 & 3,0 & 3,1 & 3,0 & 3,0 & 3,1 & 3,0 & 3,2 \\
\hline Інфраструктура & 3,8 & 3,9 & 4,1 & 4,1 & 4,2 & 4,1 & 3,9 & 3,9 \\
\hline Макроекономічна стабільність & 3,2 & 4,2 & 4,4 & 4,2 & 4,1 & 3,1 & 3,2 & 3,5 \\
\hline Охорона здоров’я та початкова & 5,7 & 5,6 & 5,8 & 5,8 & 6,1 & 6,1 & 6,0 & 6,0 \\
\hline Підвищення ефективності & 4,0 & 4,0 & 4,1 & 4,0 & 4,1 & 4,1 & 4,0 & 4,1 \\
\hline Вища освіта та професійна & 4,6 & 4,6 & 4,7 & 4,7 & 4,9 & 5,0 & 5,1 & 5,1 \\
\hline Товарний ринок & 3,5 & 3,6 & 3,8 & 3,8 & 4,0 & 4,0 & 4,0 & 4,0 \\
\hline Ринок праці & 4,5 & 4,4 & 4,4 & 4,2 & 4,1 & 4,3 & 4,2 & 4,0 \\
\hline Фінансовий ринок & 3,3 & 3,4 & 3,5 & 3,5 & 3,5 & 3,2 & 3,0 & 3,1 \\
\hline Технологічна готовність & 3,4 & 3,5 & 3,6 & 3,3 & 3,5 & 3,4 & 3,6 & 3,8 \\
\hline
\end{tabular}

Джерело: Global Competitiveness Report.

Аналізуючи дані табл. 2, можемо зробити висновок, що місце України в рейтингу має позитивну динаміку порівняно $з$ даними 2016-2017 рр. та негативну тенденцію порівняно з даними 2014-2016 pp. Позиції України змінюються з кількох причин: перш за все в результаті зміни ситуації в Україні; через зміни числа країн, які формують рейтинг; через зміну відносних позицій країн у рейтингу. Підсумковий результат демонструє невисоку конкурентоспроможність України на світовому ринку фінансових послуг.

Така ситуація зумовлена, в першу чергу, негативними тенденціями розвитку вітчизняного ринку фінансових послуг, серед яких:

1. Суттєве зменшення кількості банківських та небанківських фінансових установ в Україні, що призводить до погіршення конкурентного середовища, рівня доступності, умов надання фінансових послуг, скорочення кількості робочих місць та неготовність населення брати кредити та вкладати гроші на депозити до тих фінансових установ, які зараз функціонують через негативну репутація деяких 3 них. Так, впродовж 2012-2018 pр. вітчизняний фінансовий сектор був представлений в основному небанківськими фінансовими установами, які займали 94,2\%. Інші 5,8\% припадали на банківські установи у структурі фінансового сектору України (табл. 3) [3, 4].

За період 2012-2018 рр. кількість банківських установ зменшилася більше ніж у 2 рази - 3176 до 77 од. Тільки впродовж 2012-2013 рр. кількість банківських установ змінювалася за висхідною траєкторією, а в інші періоди, зокрема протягом 2013-2018 pp., даний показник постійно зменшу- 
вався. Найменше відхилення спо- ло 5 од. стерігалося у 2017-2018 рр. і станови-

Таблиця 2

Динаміка індексу глобальної конкурентоспроможності України за складовими групи «Розвиненість фінансового ринку»

\begin{tabular}{|l|c|c|c|c|}
\hline \multicolumn{1}{|c|}{ Показники } & $\begin{array}{c}2014-2015 \\
(144 \text { країн })\end{array}$ & $\begin{array}{c}2015-2016 \\
(140 \text { країни })\end{array}$ & $\begin{array}{c}2016-2017 \\
(138 \text { країни })\end{array}$ & $\begin{array}{c}\text { 2017-2018 } \\
(137 \text { країни })\end{array}$ \\
\hline Розвиток фінансового ринку & 107 & 121 & 130 & 120 \\
\hline Ефективність & 109 & 113 & 124 & 118 \\
\hline $\begin{array}{l}\text { - доступність до фінансових } \\
\text { послуг }\end{array}$ & 123 & 123 & 116 & 114 \\
\hline $\begin{array}{l}\text { - фінансування через місце- } \\
\text { вий ринок капіталів }\end{array}$ & 108 & 118 & 127 & 118 \\
\hline $\begin{array}{l}\text { простота доступу до кре- } \\
\text { дитів }\end{array}$ & 87 & 87 & 112 & 123 \\
\hline $\begin{array}{l}- \text { наявність венчурного } \\
\text { капіталу }\end{array}$ & 97 & 102 & 123 & 134 \\
\hline Надійність $і$ довіра & 100 & 120 & 138 & 137 \\
\hline - міцність банків & 127 & 135 & & 138 \\
\hline $\begin{array}{l}\text { - регулювання фондових } \\
\text { бірж }\end{array}$ & & & & \\
\hline
\end{tabular}

Джерело: [2]

Протягом 2012-2018 рр. склалася така структура небанківських фінансових установ: частка фінансових компаній склала у середньому $32,3 \%$; кредитних спілок - 24,7\%; ломбардів $23,4 \%$; страхових компаній - 16,4\%; недержавних пенсійних фондів - 3,5\%; адміністраторів недержавних пенсійних фондів - 1,2\%; довірчих товариств - 0,1\%. Отже, нині на ринку фінансових послуг України за кількістю переважають такі види небанківських фінансових установ, як фінансові компанії, кредитні спілки, ломбарди та страхові компанії.

Дані у табл. 3 свідчать, що серед усіх небанківських фінансових установ переважна більшість належить фінансовим компаніям. Більше того, впродовж 2012-2018 pp. їх кількість постійно зростала. Найбільші значення даного показника зафіксовано протягом 2014-2015 pp. і 2017-2018 pp., коли їх кількість зросла, відповідно, на 174 од. і 122 од. Загалом протягом усього досліджуваного періоду кількість фінансових компаній збільшилася на 537 од., з 403 од. 2012 р. до 940 од. 2018 р.

Отже, впродовж 2012-2018 рр. відбувалися зміни у кількості небанківських фінансових установ унаслідок виключення останніх 3 державного реєстру. Варто зазначити, що основні причини таких змін пов'язані з недостатнім рівнем їх платоспроможності, невиконанням ними встановлених фінансових нормативів, виявленням порушень фінансового характеру, а також прийняттям рішення фінансовою установою стосовно припинення діяльності.

Незначне зростання та низька якість активів банківських та небанківських фінансових установ. Впродовж 20162018 рр. активи вітчизняного фінансо- 
вого сектору більше чим на 90\% були представлені, в основному, активами банківських установ. При цьому, протягом вищезазначеного періоду цей показник мав тенденцію до зростання. За такою ж динамікою змінювався i обсяг активів небанківських фінансових установ. У їх структурі переважа- ли активи страхових i фінансових компаній. Структуру активів небанківських фінансових установ протягом 2016-2018 рр. складали, в основному, активи фінансових компаній, питома вага яких у середньому становила $62 \%$.

Таблиця 3

Динаміка кількості банківських і небанківських фінансових установ

\begin{tabular}{|l|c|c|c|c|c|c|c|}
\hline Показники & 2012 p. & 2013 p. & 2014 p. & 2015 p. & 2016 p. & 2017 p. & 2018 p. \\
\hline Банківські установи & 176 & 180 & 163 & 117 & 96 & 82 & 77 \\
\hline $\begin{array}{l}\text { Небанківські фінансові } \\
\text { установи у т. ч.: }\end{array}$ & 2041 & 2113 & 2087 & 2239 & 2125 & 1993 & 2024 \\
\hline Страхові компанії & 414 & 407 & 382 & 361 & 310 & 294 & 281 \\
\hline Кредитні спілки & 617 & 624 & 589 & 588 & 462 & 378 & 358 \\
\hline Ломбарди & 473 & 479 & 477 & 482 & 456 & 415 & 359 \\
\hline Фінансові компанії & 403 & 492 & 537 & 711 & 809 & 818 & 940 \\
\hline Довірчі товариства & 2 & 2 & 2 & 2 & 2 & 2 & 2 \\
\hline $\begin{array}{l}\text { Недержавні пенсійні фо- } \\
\text { Адміністратори недер- } \\
\text { жавних пенсійних фондів }\end{array}$ & 37 & 81 & 76 & 72 & 64 & 64 & 62 \\
\hline Інші фінансові установи & 1 & - & - & - & - & - & - \\
\hline
\end{tabular}

Джерело: $[3,4]$

Низький рівень фінансової обізнаності та грамотності населення України, яке змушене самостійно отримувати знання та інформацію щодо фінансових установ та послуг, що ними надаються. Так, серед усього спектру фінансових послуг, 2018 р. громадяни обирали переважно такі фінансові послуги, як фінансовий лізинг $(22,2$ млрд. грн), фінансові кредити $(66,6$ млрд. грн), факторинг (48,1 млрд. грн), страхування $(34,4$ млрд. грн чистих страхових премій за укладеними договорами страхування), 3 них 44,6\% (15,3 млрд. грн) припадає на добровільні види майнового страхування, а $17,8 \%$ (6,1 млрд. грн) - добровільне особисте страхування та $16,7 \%$ (або
5,7 млрд. грн) - обов'язкове страхування цивільної відповідальності власників транспортних засобів (рис. 1) [5]. При чому саме їх обсяги протягом 2016-2018 рр. мали тенденції зростання.

Уповільнений розвиток фондового ринку. Основними, причинами цього $\epsilon$ недосконалість нормативно-правової бази, низький рівень захисту прав інвесторів та акціонерів, нерозвиненість фінансової та фондової інфраструктури, недостовірність інформації про функціонування підприємства тощо. Так, загальний обсяг випусків емісійних цінних паперів, зареєстрованих Національною комісією 3 цінних паперів та фондового ринку у січні- 
грудні 2019 р., становив 112680,0 млн. протягом 2015-2017 рр. спостерігався грн., що більше на 52325,2 млн. грн порівняно 3 відповідним періодом 2018 p. (60342,1 млн. грн.). Проте, значно більший обсяг випусків емісійних цінних паперів (рис. 2) [6].

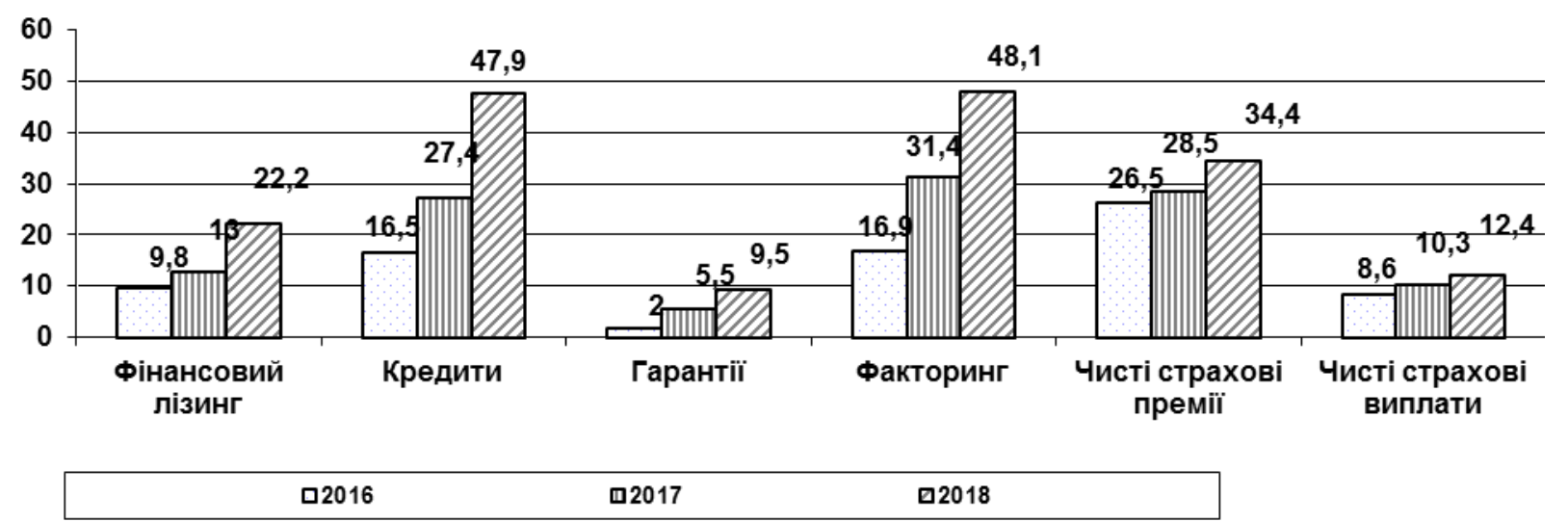

Рис. 1. Динаміка обсягів фінансових послуг, млрд. грн Джерело: [5]

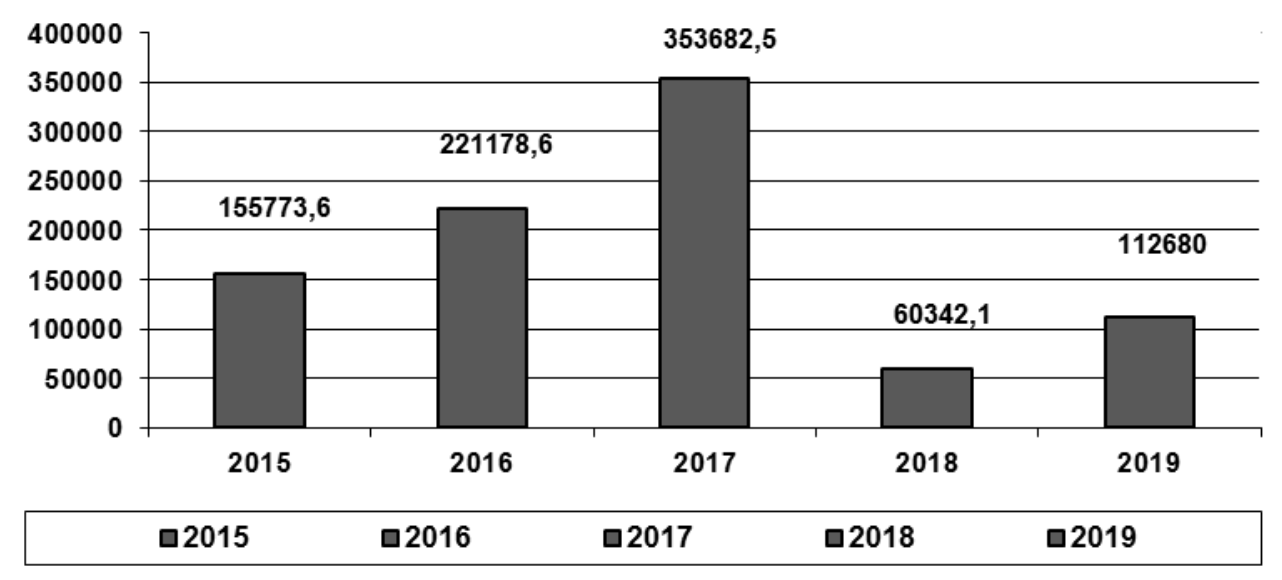

Рис. 2. Динаміка обсягу випусків емісійних цінних паперів, млн. грн. Джерело: [6]

Окрім того, до перешкод, що стоять на заваді конкурентоспроможності ринку фінансових послуг України, слід віднести такі [5]:

- обмеженість інструментів у частині заходів впливу щодо порушень вимог до платоспроможності, які виявлені за результатами пруденційного нагляду на ринках фінансових послуг;

- відсутність механізмів, що виводять 3 ринку небанківських фінансових послуг фінансових установ, які не виконують свої зобов'язання перед споживачами ринків небанківських фінансових послуг i, тим самим, створюють суттєві системні ризики для сектору;

- недосконалість інформаційнокомунікаційних технологій при взаємодії з учасниками ринку;

- недостатність інформації та знань у споживачів фінансових послуг, які необхідні для обгрунтованого вибору фінансової послуги, а також 
оцінки рівня власних ризиків та майбутніх зобов'язань під час вибору фінансової послуги;

- невідповідність чинного законодавства, яке регулює ринок фінансових послуг, потребам та сучасному стану розвитку його учасників;

- відсутність єдиного стандартизованого електронного формату розкриття інформації у фінансовій звітності в порівнянні з найкращими світовими практиками (XBRL), що створює перешкоди в частині зрозумілості та прозорості для потенційних іноземних інвесторів ринку фінансових послуг;

- неналежний рівень наближення регуляторного середовища ринку фінансових послуг до міжнародних стандартів регулювання та нагляду в частині державного регулювання та нагляду відповідно до стандартів IAIS, IOPS та Solvency II;

- недостатність розвитку національної системи професійної сертифікації актуаріїв та недостатня кількість кваліфікованих актуаріїв на ринку страхових послуг, здатних виконувати актуарні розрахунки на високопрофесійному рівні;

- недостатність інструментів забезпечення захисту прав споживачів, у т.ч. відсутність системи гарантування на ринках страхування життя, кредитних спілок та недосконалість механізмів гарантування на ринку ОСЦПВ;

- низький фінансовий рівень спроможності громадян брати участь у системі недержавного пенсійного забезпечення та низький рівень довіри населення до цього фінансового ринку як споживача його послуг;

- недостатня зацікавленість роботодавців у фінансуванні недержавних пенсійних програм для працівників;
- збільшення ризиків, пов'язаних iз фінансовою нестабільністю, у т.ч. неповернення пенсійних активів, які розміщені на депозитних рахунках банківських установ, до яких Національним банком України введено тимчасову адміністрацію або по яких прийнято рішення про їх ліквідацію та обмежений вибір фінансових інструментів, придатних для інвестування в них пенсійних коштів, внаслідок відставання розвитку ринку капіталу від потреб інституційних інвесторів;

- незначний розвиток та популяризація корпоративних недержавних пенсійних фондів.

Таким чином, низький рівень конкурентоспроможності України на світовому ринку фінансових послуг, значною мірою, $є$ наслідком недорозвиненості їі внутрішнього ринку фінансових послуг. Ключові індикатори розвитку ринку (надійність банківської системи, стан регулювання фондового ринку, доступність фінансових послуг та можливість залучення ресурсів через локальний ринок капіталів) є набагато нижчими, ніж у інших країн аналізованого сегменту. Подальший його багатовекторний розвиток ринку фінансових послуг потребує комплексного підходу до усунення зазначених причин.

В сучасних реаліях фінансовий сектор України працює в умовах прийнятої 2020 р. «Стратегії розвитку фінансового сектору України до 2025 року» [7], заходи якої спрямовані на реформування сектору фінансових послуг 3 акцентом на інтеграцію до ЄС. На наш погляд, якщо відбудеться вжиття хоча б якоїсь частки запланованих у цій Стратегії заходів, то ринок фінансових послуг повинен перейти на певний новий якісний рівень, проте під питан- 
ням залишається зростання конкурентоспроможності України на світовому ринку фінансових послуг. Зменшення показників експорту фінансових послуг у 2,5 рази у 2019 р. порівняно 3 2015 р., зокрема страхових послуг, свідчить про значне зменшення світової конкурентоспроможності. 3 іншого боку, сьогодні відбувається вжиття санаційних заходів сектору фінансових послуг, які, на думку урядовців, повинні зміцнити самих фінансових посередників, відповідно, результат це може дати лише через певний час.

Проте якщо звернутись до концепції М. Портера, то можна сказати, що, окрім інновацій, ніщо не може зміцнити конкурентні позиції фінансових посередників, відповідно, запропоновані заходи держави ніяким чином позитивно не відобразяться на підвищенні конкурентоспроможності України на світовому ринку фінансових послуг. Перш за все в Україні необхідно сфокусуватись на створенні спеціалізованих факторів. Держава має бути відповідальною за базову та вищу освіту, базову інфраструктуру, охорону здоров’я, а компанії повинні розвивати передові, спеціалізовані та специфічні галузі та кластери.

В межах державної стратегії формування світового фінансового центру в Україні необхідно вибрати обласні центри 3 відносно добре розвиненою сьогодні транспортною, телекомунікаційною, готельною, освітньою мережею, на базі яких слід удосконалювати фінансову інфраструктуру. Такими центрами рекомендуємо вибрати Київ, Львів, Одесу та Харків. Відповідно, разом 3 обов'язковими банківськими послугами для всіх центрів, в кожному 3 них слід додатково вибрати певну фінансову спеціалізацію. Так, наприклад, Києву варто надати найскладнішу задачу розвитку фондового ринку, відповідно, сконцентрувати всі зусилля на операціях 3 цінними паперами. За Львовом необхідно закріпити послуги зі страхування та перестрахування, зокрема міжнародного товарообігу. Одесі треба надати повноваження розвитку ісламських фінансових послуг, а Харкову - фінансові послуги, пов'язані 3 китайською валютою ренмімбі.

Залежно від вибраної спеціалізації необхідно почати адаптацію вищої освіти, курсів підвищення кваліфікації, процес вивчення міжнародного досвіду надання фінансових послуг. Обов'язково слід запровадити вивчення шести іноземних мов, які $є$ офіційними мовами ООН (англійська, арабська, іспанська, китайська, російська і французька), а також сформувати підвищений бюджетний набір на спеціальності міжнародних економічних відносин, фінансів, програмування, іноземних мов, які $\epsilon$ ключовими для міжнародного фінансового центру.

Паралельно 3 цим держава повинна слідувати спеціальній програмі щодо податкового стимулювання саме стратегічних напрямів у вибраних центрах, що автоматично сконцентрує відповідних фінансових посередників. В реаліях України дуже важливо, щоб деклараційним чином заявлена державна стратегія відповідала дійсності.

Серед спеціальних заходів, що запустять процес формування міжнародного фінансового центру в Україні та автоматично підвищать іiі конкурентоспроможність на світовому ринку фінансових послуг, можна виділити такі: 
1. Підвищити загальну конкурентоспроможність країни, зокрема змінити фінансові послуги відповідно до потреб бізнесу, впровадити фінансові інновації, розширити види фінансових послуг. Для цього необхідно створити агентство фінансових інновацій 3 наявністю експертів найвищого професіонального рівня, під час звернення до якого автоматично будуть вноситись корективи до законодавства щодо надання можливості впровадження окреслених фінансових інновацій у діяльність відповідного фінансового посередника [8].

2. Забезпечити доступність фінансових послуг та простоту доступів до кредитів в Україні, що можна здійснити шляхом впровадження онлайнобслуговування як резидентів, так i нерезидентів.

3. Підвищити стійкість банків за рахунок забезпечення достатнього обсягу власного капіталу (за відсутності надлишкового); збалансованості структури активів та пасивів за строками і сумами; належного рівня рентабельності діяльності банку та його підтримки. Частково це легше зробити в економіці, що розвивається, а для України, на жаль, сьогодні ситуація ускладняється несприятливою економічною ситуацією.

4. Поліпшити силу законних прав, що може бути здійснене за рахунок [9] удосконалення законодавства щодо забезпечених угод, неплатоспроможності, фідуціарної передачі права власності на об'єкт, фінансового лізингу, дебіторської заборгованості та прямого переказу дебіторської заборгованості, угод 3 тимчасовим зберіганням права власності. Також необхідно забезпечити ведення реєстрів фідуціарної передачі права власності на об'єкт, угод щодо фінансового лізингу, дебіторської заборгованості і прямого переказу дебіторської заборгованості, угод з тимчасовим зберіганням права власності, які $є$ вагомими для третіх осіб, заставного забезпечення. Відповідно до наявної світової практики доцільно дати змогу об'єктам, що перебувають у власності жінок (ювелірні прикраси, побутова техніка, меблі), виступати заставою за комерційним кредитом. Слід забезпечити можливість використання як окремо, так і в поєднанні дебіторської заборгованості запасів, матеріального рухомого майна як заставного забезпечення, а також таких рухомих активів, як майбутні активи, набуте майно, як забезпечення за кредитом. Варто забезпечити можливість використання як застави майбутні, умовні, грошові, негрошові борги та зобов'язання. Необхідно забезпечити пріоритетність виплати боргів у разі ліквідації або банкрутства боржника, а розпочати слід 3 тих, які перебувають у реєстрі.

Глибину кредитної інформації, відповідно до Стратегії [7], вже покращують, що має позитивно відобразитись на однойменному індексі, такі ж позитивні зрушення простежуються і за часткою дорослих, що зареєстровані в кредитному бюро, а також часткою дорослих, що внесені в кредитний реєстр. Відповідно до джерела [10] необхідно в кредитну інформацію в Україні внести такі дані, як інформація фінансовим посередникам про фірми та приватні особи, які бажають взяти кредит; кредитна історія (як позитивна, так і негативна); дані про пов'язані компанії з фінансовими інститутами за останні два роки. Вартість інформації повинна бути 
нижчою за 1\% доходу на душу населення. Повинна забезпечуватись доступність інформації для самих позичальників про власну кредитну історію.

Також варто впровадити послугу для банків і фінансових установ 3 кредитного рейтингу позичальників. Доцільно розширити покриття населення в базі даних кредитних бюро та реєстраторів, що збільшить частку дорослих, що зареєстровані в кредитному бюро та кредитному реєстрі, відповідно, збільшить показник отримання кредитів, а водночас i конкурентоспроможність країни на світовому ринку фінансових послуг. Також на законодавчому рівні в Україні необхідно лібералізувати обмеження щодо впровадження нових фінансових послуг, що може реалізуватись через запропоноване раніше експертне агентство. На законодавчому рівні доцільно посилити захист міноритарних інвесторів через комплексний підхід, що вносить корективи в положення щодо цінних паперів, корпоративних законів, цивільно-процесуальних кодексів та правил судової думки.

В межах державної стратегії розвитку України як світового фінансового центру доцільно зобов'язати потенційне експертне агентство фінансових послуг проводити постійну роботу зі спрямування фінансових посередників в напрямі розширення послуг іноземним споживачам, зокрема стимулювати створення іноземних відділень. В Україні це є можливим за умови спільної кооперації декількох банківських установ зі значним обсягом фінансових ресурсів. Паралельно в країні необхідно розвивати потужну правову систему, зокрема послуги, пов'язані із захистом українських фінансових посередників за кордоном. Для України за кордоном за умов обмеженості капіталу доцільно зосереджуватись на роздрібних фінансових послугах, а також супроводі українського бізнесу за кордоном.

Для всіх українських банків, на нашу думку, доцільно розробляти нові фінансові продукти для бізнесу та населення, що також стосується інших суб'єктів ринку фінансових послуг, зокрема страхових компаній. Варто зосередити увагу на розширенні доступності фінансових послуг для населення; вжитті заходів щодо розширення освіченості населення, рекламних акцій, відкриття рахунків за спрощеною процедурою, зокрема не тільки в банківських установах, але й в інститутах партнерської мережі, що більш тісно працює 3 населенням; зниженні вартості ведення рахунків; автоматичному відкритті банківського рахунку під час користування будьякою банківською послугою [11].

Банкоматно-термінальна система в Україні користується великим попитом, тому доцільно розширяти іiі покриття, зокрема в сільській місцевості, або забезпечувати дистанційне та віртуальне обслуговування клієнтів віддалених місць. В сучасних реаліях України підвищення витратної частини бюджету сім’ї, на жаль, дуже важко фінансовим установам акумулювати національні депозитні кошти, тому стратегія оперування на іноземних ринках $є$ певним виходом. Важливо також українським фінансовим посередникам працювати над іміджом надійності і формувати довіру, зокрема до банківських установ.

Потенційному експертному агентству фінансових послуг в Україні необхідно вживати заходів щодо сти- 
мулювання банками підтримки свого іміджу, здійснення більш жорсткого контролю над діяльністю фінансових установ, що спрямований на підтвердження професіоналізму співробітників і керуючих фінансовими установами, запобігання банкрутству фінансових установ, жорсткої правової відповідальності за недоброякісну роботу, пов'язану з обманом та незаконним заволодінням фінансовими коштами споживачів фінансових послуг.

На рівні держави уряд повинен стимулювати соціально-економічне зростання в країні, що збільшить благополуччя населення, в результаті чого зростатиме дохідна частина бюджету сім'̈̈, знизяться комунальні виплати, а також вартість транспортної логістики для населення. Важливим $є$ проведення політики зменшення облікової ставки, а також оптимізації діяльності таким чином, щоб мати можливість підвищити ставку по депозитам.

В Україні доцільно збільшувати доступність населення до фінансових послуг, зокрема за рахунок відкриття нових філій, або підійти до покриття більш інноваційно. Ще одним напрямом є збільшення кредитного покриття, що, на нашу думку, можливе лише за кардинального зменшення відсоткових ставок по кредиту. Ефективність ринку фінансових послуг виявляється також у збільшенні кількості фінтехкомпаній, появу яких в Україні доцільно стимулювати, а ро- зробки яких слід впроваджувати у діяльність фінансових посередників. Також варто допускати на український ринок іноземних фінансових посередників зі значною позитивною історією та переймати їх досвід.

Сьогодні Україна стала більш відкритою для іноземних фінансових посередників, що виявилось у значному збільшенні імпорту фінансових послуг, що може позитивно вплинути на конкурентоспроможність України на світовому ринку фінансових послуг [12]. Такий процес, на нашу думку, гальмувати недоцільно, що пов'язано 3 передачею світового досвіду. Весь час фінансові посередники повинні працювати над збільшенням власних активів, відповідно, українські компанії не є винятком.

Висновки. Отже, Україна на сьогодні перебуває на тому етапі розвитку, коли потрібно здійснювати явні стратегічні дії щодо пошуку нових конкурентних позицій на світовому ринку. Для підвищення конкурентоспроможності України на світовому ринку фінансових послуг доцільно поставити мету розвитку країни як світового фінансового центру 3 виділенням спеціалізації за чотирма основними напрямами, а саме: на операціях 3 цінними паперами, страхуванні міжнародних торгових потоків, ісламських фінансових послугах, операціях $з$ китайською валютою ренмімбі.

Список використаної літератури

1. Україна втратила позиції у світовому рейтингу конкурентоспроможності. URL: https://www.epravda.com.ua/news/2019/10/9/ 652410/ (дата звернення 23.02.2020). 
2. Позиція України в рейтингу країн світу за індексом глобальної конкурентоспроможності 2017-2018. URL: http://edclub.com.ua/analityka/ pozyciya-ukrayiny (дата звернення 23.02.2020).

3. Основні показники діяльності банків України за 2012-2018 pp. URL: https://bank.gov.ua/control/uk/publish/article?art_id=34661442 (дата звернення 23.02.2020).

4. Публічні звіти про діяльність Національної комісії, що здійснює державне регулювання у сфері ринків фінансових послуг за 2012-2018 pp. URL: https://www.nfp.gov.ua/ua/Richni-zvity-Natskomfinposluh.html (дата звернення 23.02.2020).

5. Стратегічний план діяльності Національної комісії, що здійснює державне регулювання у сфері ринків фінансових послуг на 2020-2022 рр.: затв. розпорядженням Національної комісії, що здійснює державне регулювання у сфері ринків фінансових послуг від 04.06.2019 p. № 1021. URL: https://www.nfp.gov.ua/files/DepFinMon/Strategy/C\%D1\%82\%D1\%80\% D0\%B0\%D1\%82\%D0\%B5\%D0\%B3\%D1\%96\%D1\%87\%D0\%BD\%D0\%B8\%D0\% B9_\% D0\%BF\%D0\%BB\%D0\%B0\%D0\%BD_2020-2022.pdf (дата звернення 23.02.2020).

6. Аналітичні дані щодо розвитку фондового ринку. URL: https://www.nssmc.gov.ua/news/insights/ (дата звернення 23.02.2020).

7. Стратегія розвитку фінансового сектору України до 2025 року. URL: https://mof.gov.ua/storage/files/Strategija_financovogo_sectoru_ua.pdf (дата звернення 23.02.2020).

8. Литвин О.С., Білошапка В.В. Особливості цифрового маркетингу в банківській діяльності. Фінансовий простір. 2020. №4 (40).

9. Doing Business 2018: Getting Credit - Legal Rights Questionnaire. 2018. 18 p. URL: http://www.doingbusiness.org/ /media/WBG/DoingBusiness/Documents/ Methodology/Survey-Instruments/DB18/DB18-Legal-Rights-Creation questionnaireen.pdf?la=en (дата звернення 23.02.2020).

10. Getting Credit Methodology. Doing Business. 2017. URL: http://www.doingbusiness.org/Methodology/Getting-Credit (дата звернення 23.02.2020).

11. Литвин О.С. Нові підходи до шляхів підвищення ефективності банківської системи України // Механізми забезпечення ефективності та конкурентоспроможності банківської системи та економіки України: 
монографія за заг. ред. д.е.н. Г.Т. Карчевої. Київ: ДВНЗ «Університет банківської справи», 2019. С. 279-287.

12. Литвин О. Україна в системі міжнародних економічних відносин в умовах інституціоналізації та глобальної конвергенції. Вісник Київського національного університету імені Тараса Шевченка. Міжнародні відносини. 2019. Вип. 1(49). C. 36-40. 